\title{
Staande de zitting : een beschouwing over het onmiddellijkheidsbeginsel
}

Citation for published version (APA):

Mols, G. P. M. F. (1989). Staande de zitting : een beschouwing over het onmiddellijkheidsbeginsel. Gouda Quint. https://doi.org/10.26481/spe.19890518gm

Document status and date:

Published: 18/05/1989

DOI:

10.26481/spe.19890518gm

Document Version:

Publisher's PDF, also known as Version of record

\section{Please check the document version of this publication:}

- A submitted manuscript is the version of the article upon submission and before peer-review. There can be important differences between the submitted version and the official published version of record.

People interested in the research are advised to contact the author for the final version of the publication, or visit the DOI to the publisher's website.

- The final author version and the galley proof are versions of the publication after peer review.

- The final published version features the final layout of the paper including the volume, issue and page numbers.

Link to publication

\footnotetext{
General rights rights.

- You may freely distribute the URL identifying the publication in the public portal. please follow below link for the End User Agreement:

www.umlib.nl/taverne-license

Take down policy

If you believe that this document breaches copyright please contact us at:

repository@maastrichtuniversity.nl

providing details and we will investigate your claim.
}

Copyright and moral rights for the publications made accessible in the public portal are retained by the authors and/or other copyright owners and it is a condition of accessing publications that users recognise and abide by the legal requirements associated with these

- Users may download and print one copy of any publication from the public portal for the purpose of private study or research.

- You may not further distribute the material or use it for any profit-making activity or commercial gain

If the publication is distributed under the terms of Article $25 \mathrm{fa}$ of the Dutch Copyright Act, indicated by the "Taverne" license above, 
Staande de zitting 
Vour Maria, Clave, Violete, Danuel, Iris en Syluian 


\section{Staande de zitting}

Een beschouwing over het onmiddellijkheidsbeginsel

Rede

uitgesproken ter gelegenheid van de aanvaarding van het ambt van gewoon hoogleraar in het straf-en strafprocesrecht aan de Rijksuniversiteit Limburg te Maastricht op donderdag I 8 mei 1989

door

mr. G.P.M.F. Mols

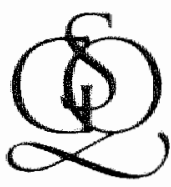

GOUDA QUINT BV ARNHEM 
Tekeningen: mr. Maria Mols-Kemne

CIP-GEGEVENS KONINKLIJKE BIBLIOTHEEK, DEN HAAG

Mols, G.M.M.

Stande de zitting: een beschouwing over het on middellijkheidsbeginsel/G.P.M.F. Mols - Arnhem: Gonda Quint. - III.

maugurele rede Mastricht.

ISBN $00-6000-627-5$

SISO 395.1 UDC 343.13(043.5) NUGI 694.

Trefw: strafrecht; Nederland/strafprocesrecht; Nederland.

(C) 1989 G.M.M.M.Mols

Alle rechten woorbehouden. Niets ut deze uitgave mag worden vervechoudigd, opgeslagen in een geatomatiseerd gegewensbestand, of openbatar gemakt, in mige vorm of op enige wijze, herzij clektronisch, mechanisch, door fotocopieün, opnamen, of enige andare manier, zonder woorafgande schriftelije toestemming van de witgever.

Voor zover het maken wankopiën unt deze uitgave is toegestan op grond wan artikel $6 \mathrm{~B}$ Autcurswet 1912 jo. het Bestuit wan 20 juni 1974, Stb. 351, 20als gewijzigd bij het Besluit van 23 atgustus $1085,5 \mathrm{rb}$. 47 I artikel 17 Auteurswet 1912 , dient men de darvoor wettelijk werschuldigde vergoedingen te voldoen an de Stichting Reprorecht (Postbus 882,1180 AW Amstelveen). Voor het overnemen van gedeele(n) wit deze uitgave in bloentlezingen, readers en andere complatiewerken (arrikel r6 Auteurswet 19r2) dient men zich tot de nitgever te wender 


\section{Dames en Heren}

\section{Inleiding}

Het is niet dan na enige aarzeling dat ik u de vraag wil voorhouden: waartoe dient het eindonderzoek in strafzaken? Het is als met zoveel vragen. Op het eerste gezicht lijken ze overbodig maar bij nadere bestudering blijken de zo voor de hand liggende antwoorden problematischer dan wordt verondersteld. De vraag naar de betekenis van het eindonderzoek in strafzaken is op zichzelf niet nieuw. In zijn in 1974 verschenen klassiek geworden opstel 'Vooronderzoek of eindonderzoek beslissend?' heeft de Utrechtse strafrechtsgeleerde Pompe al een vinger op deze zwakke plek gelegd.' In tegenstelling tot wat de theorie ons wil doen geloven blijkt in de praktijk het voorbereidend onderzock in strafzaken in verreweg de meeste gevallen beslissend te zijn. En wie denkt dat er sinds Pompe iets fundamenteels gewijzigd is aan deze situatie in die zin dat het voorbereidend onderzoek weer hersteld is in zijn oorspronkelijke status net het accent op het bestanddeel voorbereidend, heeft het mis. Slechts zij die de hoop koesteren dat in het beslissend voorbereidend onderzoek de positie van de verdachte wordt versterkt juist ondat die fase beslissend is voor de uitkomst van het strafproces, hebben het gelijk aan hun kant, zij het onder antekening dat vooralsnog die hoop ijdel is gebleken, nu zeer recent nog de minister ondanks uitvoerige studie met anderslluidende conclusie, de radsman geen toegang tot het politieverhoor heeft willen verlenen. ${ }^{2}$

: W. J. Pompe: Vooronderzock of cindonderzock beslisernd? in: Vijf opstellen wan Willem Pormpe, Zwolle 1974.

${ }^{2}$ Zic a.m. C. Fijnaur De toelating van radsliedon tot het policieles werdachtenverhoor. Amhem, Antwerpen, $198 \%$.

J.A.W. Lensing: Het werthoor van de verdachte in strafzaken, diss. Nijmegen, A mhem 1988. 
De vragg nat de betekenis van het eindonderzoek is van belang voor de beoordeling van het hele strafproces. Gepolariseerd luidt zij als volgt: Is het onderzoek ter zitting bedoeld als cen zelfstandig onderzoek dat moet leiden tot een oordeel van een onafhankelijke rechter op basis van persoonlijke confrontatie ter zitting met het bewijsmateriaal (de optimum-hypothese), of gat het om cen formeel noodzakelijke bijeenkomst, gevolgd op de afwezigheid van enige wijze van buitengerechtelijke afdoening, tijdens welke bijeenkomst de rechter zich beperkt tot het toetsen van zijn door het dossier gevormd voorlopig oordeel? (de nul-hypothese). De theorie neigt naar de optimumthese, de alledaagse praktijk naar juist de andere kant.

Het eindonderzoek ter zitting is in onze vaderlandse strafrechtspleging in de regel een buitengewoon saai gebeuren, waar met name de voordrachtskunsten van de voorzitter een centrale plaats lijken in te nemen, en waar een zodanig grote hoevelheid stukken voorhanden is dat daardoor niet zelden het zicht van de rechter op verdachte en getuige ernstig wordt belemmerd, en zo de verdachte de rechter letterlijk niet ziet zitten.

Belangrijker dan deze fysieke zaken is het gegeven dat m.n. doelmatigheid en efficiëntie de idealen van de optimumthese wezenlijk hebben aangetast, en daarmee het rechtskarakter van het strafrecht ondermijnen. ${ }^{3}$

\section{Het beginsel der onmiddellijkheid ${ }^{4}$}

In reactie op het voormalige geheime strafproces wordt thans aan het eindonderzoek als eis gesteld dat het in het openbaar mondeling wordt

"A.A.G. Peters: Het recheskataker wan het strafreche, oratie Utrecht, Deventer 1972.

"Hierover o.m.: Klaus Geppert: Der Grundsatz der Unmutelbarket im deutschen Strafvertahren, Berlin 1979: C.J. A. Mittermaier: Die Mündlichkeit in den verschiedenon Geretzgubungan, herdr. Leipzig 1970, J.F. Nijboer Enkole opmerkingen over de betekenis wan hee onmiddellijkheddsbeginsel in het strafprocesrecht, in: NJB, $20 \mathrm{okt}$. 1979, at1. 36, p. 321-824, H.E. Lohr: Der Grundsatz der Unmitrelbarkeit in deutschen Strafprozessrecht, Berlin 1972; S.A.M. Stolwijk: Het onderzoek ter terechtzitring in strafaken diss. Leiden, Amhem 5972 , en nav. de-auditu-jurisprudentie o.m. W. Pompe. Her bew yjs in srafaken, Mededelingen Koninklijke Vlaamse Academie voor Wetenschappen, Leteren en Schone Kunsten, Klase der Letreren, XXI, 1959. 
gevoerd voor een ona thankelijke rechter die geroepen is een beslissing te nemen, bij voorkeur op basis van het beste bewijsmateriaal dat voorhanden is. Dit heet het onmiddellikheidsbeginsel. Aan dit beginsel onderscheid ik een drietal aspecten met verschillend perspectief.

Het eerste aspect betreft de positie van de verdachte. Door de presentatie ter zitting in aanwezigheid van de verdachte van aanklacht en bewijsmateriaal, wordt deze in de gelegenheid gesteld zijn verdediging onmiddellijk en gedetailleerd te voeren. $H_{i j}$ kan ter zitting tegen de beschuldiging en het aangebrachte bewijsmaterial alles aanvoeren wat volgens hem tot verdediging strekt. De mate waarin aan dit aspect vorm en inhoud wordt gegeven is bepalend voor het accusatoire gehalte van dit deel van het strafproces, dat door Pompe vanwege het accusatoire karakter een beslissende rol wordt toebedeeld, een standpunt dat ik volledig onderschrijf.

Het tweede aspect betreft de rechterlijke functie. De zittingsrechter is geroepen om over de schuldwraag een zelfstandig oordeel te geven in volstrekte onafhankelijkheid. Dat dit dient te gebeuren naar aanleiding van het onderzoek ter zitting waarin al het bewijs de revue passeert, is een logisch gevolg van het terechte verzet tegen de geheime schriftelijke strafprocedure waarin met het inquisitoire element ook het politionele karakter werd versterkt. Het onderzoek ter zitting is dan niet meer dan een voortzetting van het politieoptreden, zonder een duidelijke schei-

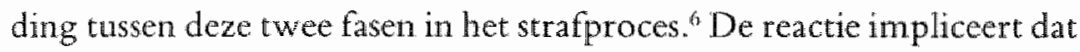
ter zitting alle getuigen worden gehoord en gezien door de rechter zodat hij daad werkelijk een zelfstandig oordeel kan geven over de kwaliteit en de mate van betrouwbarheid van het getuigenbewijs. Bovendien maakt de verschijning van de getuigen ter zitting het eenvoudig om eventuele onvolkomenheden in het voorbereidend onderzoek recht te zetten. Meest wezenlijk is dat door de verschijning van getuigen ter zitting het dialectisch proces van warheidsvinding vorm en inhoud wordt gegeven. De procespartijen en de rechter zijn in de gelegenheid om vragen te stellen en getuigen te confronteren met andere informatie enfof tegenstrijdigheden in hun verklaring, op zoek naar de waarheid.

5 W. Pompe, 1974, a w.

"Zic huevover o.a. M. van de Vrugt. De crimincle ordonnantien van 1570 . Enkele beschouwingen over de eerste strafrechtcodificatie in de Nederlanden, diss. Utrecht, Zutphen 1978, p. 135 . 
Plechig gezegd: de dialectiek van het recht op waarheid, onder regie van de iudex.

Het derde aspect betreft de openbarheid, de precaire hoeksteen van iedere democratische rechtstat. On democratische controle, rechtsgelijkheid en uiteindelijk om de idealen van onze strafrechtspleging mogelijk te maken is openbaarheid een eerste vereiste. Dat impliceert volledige presentatie ter zitring van alle argumenten en kwaliteiten in geding, of precieser, de beste argumenten en kwaliteiten die parrijen voorhanden hebben.?

De kern van het onmiddellijkheidsbeginsel is gelegen in de presentatie ter zitting van alles wat voor de juridische en daarmee politick-rechtsstatelijke beoordeling van de zaak van belang is. De confrontatie van de procespartijen en de rechter met de beschuldiging en met het bewijsmaterial is essenticel. Woor een scherper begrip van de juiste inrichting van het eindonderzoek ter zitting zou ik liever willen spreken van het confrontaticbeginsel. ${ }^{8}$ Een eindonderzoek dat niet of onvoldoende aan dit beginsel tegemoet komt, doet in dezelfde mate afbreuk aan alle drie hiervoor genoemde aspecten: het accusatoite karakter, de autonome rechterlijke functie, en de openbaarheid van de strafrechtspleging. Waar elk afzonderlijk, in onderling verband geldit dit nog sterker, beoogt een bijdrage te leveren an het rechesgehalte van het strafrecht ten behoeve van een rechtvaardige juridische strafrechtspleging, is alke relativering van het onmiddellijkheids- of confrontatiebeginsel ongekeerd een aantasting van diezelfde juridische $k$ waliteit van de strafrechtspleging.

Het onmiddellijkheidsbeginsel is een kritisch beginsel en heeft als zodanig nooit absoluut gegolden." Er zijn altijd wel uitzonderingen op geweest zowel formeel als praktisch. Formeel kan men denken an de strafrechtspleging van jeugdigen. Praktisch gaat het om mensenwerk, of precieser om de rol die de zittingsrchter speelt bij de realisering van het

"Aan dk recher worde aldus de mogelijkheid geboden om het beste bewijsmaterial dat voorlanden is te gebruiken.

"I deze zin ook A.A.G. Peters in zijn noot bij HR 7 december 1971, NJ 1972, r97 in: A.A 1973. p. $236-253$.

"Hicrover m.n. Mittermater" a.w.

Zive voor de aitzonderingen in het Nedertandse strafproces: D. Simons: Beknopte handering tot het Wetboek van Strafvordering, fo dr. Haarlem 1925. p. 33-34. 
beginsel. Mijns inziens is die rol van doorslaggevende betekenis. Sinds de anvaarding van de de-audituverklaring, de erfzonde van het strafprocesrecht, is, ondanks de bij herhaling door de Hoge Raad bevestigde en benadrukte vrijheid wan de rechter bij de waardering van het bewijsmateriaal, het onmiddellijkheidsbeginsel in zodanige mate gerelativeerd dat sommigen zich afvragen of het wel een beginsel is dat aan onze strafrechtspleging ten grondslag ligt. In elk geval is in de alledaagse praktijk de confrontatie tijdens het strafproces tot minimale proporties teruggebracht. De getuige ter zitting is in de modale strafzaak een zonderlinge verschijning geworden, en het onderzoek beperke zich tot het voorhouden van processen-verbal, wan gedeelten daaruit, en soms slechts van gedeelten uit zinnen uit het proces-verbal.

Daarmee is noch de verdachte, noch de openbaarheid gediend, terwijl het zeer de vraag is of deze gang van zaken de waarheidswinding bevordert. De vrijheid van de zittingstechter om inhoud te geven aan het beginsel van confrontatie lijkt in de praktijk vooral te worden opgevat als de afwezigheid van de verplichting om ter zitting getuigen te horen en bewijs in ogenschouw te nemen. Van belang voor deze rechterlijke keuze lijkt het perspectief van waaruit de rechter het eindonderzoek en zijn eigen positie daarin benadert. Als diegene aan wie de eindbeslissing is voorbehouden, moet hij in meer of mindere mate kiezen tussen enerzijds de rechtshandhaving als primair doel van de strafrechtspleging, en anderzijds het ordeningsmodel waarin de bestrijding van criminaliteit, de efficiency van de strafrechtspleging in het algemeen en van het eindonderzoek in het bijzonder een dominante plaats innemen. De optiek van de rechtshandhaving opent meer perspectieven voor het confrontatiebeginsel om dat het daarbij niet zozeer gat om de vraag of er een beslissing wordt genomen, mar vooral hoe die beslissing tot stand komt. De due process gedachte en de wardering van het contradictoire karakter van het strafproces overschaduwen de behoefte aan snelheid en efficiency. In het ordeningsmodel darentegen wordt het strafproces primair getoetst aan criteria van doelmatigheid en neemt de Funktionsfahigkeit van het strafproces in verband net de criminaliteitsbestrijding een primaire plaats in. ${ }^{10}$ In deze benadering

15. Zie in dit verband ook C.J.M. Schuyt: Tussen macht en moral, over de plats want loe reche in werzorgingstaat en democratie, Alphen a.d. Rijn, 1983, n.n. p. $43^{-1} 144$, en voorzover her de persoon van de rechter betreft P.C. wan Duyne en J.R. A. Verwourd: 
bestaat weinig bezwart tegen de naadloze overgang van het vooronderzoek in het eindonderzoek, oftewel gecharcheerd, in het ongehinderd doorstromen van gedeelten van het politie-proces-verbaal in het rechterlijk eindwonnis. Het ordenings- of bestrijdingsmodel is weinig confrontatiegezind, en biedt ruimte voor een low profile benadering van beginselen en de verdachte beschermende rechten. De relativering van het confrontatiebeginsel heeft gevolgen voor de mate waarin de equality of arms kunnen worden gerealiseerd, en minimaliseert bovendien de controleerbaarheid van de strafrechtspleging, terwijl de rechterlijke functie gemarginaliseerd lijkt te worden tot een stempelfunctie voor het opsporings-proces-verbaal met als inhoud: gezien en accoord. Het verschijnsel van de anonieme getuige kan worden beschouwd als een valu de wuchter. van deze rechterlije takopvatting. ${ }^{11}$

Gradueel kunnen gemeten naar de mate waarin aan het onmiddellijkheidsbeginsel inhoud wordt gegeven, een drietal typen van zittingsrechters worden onderscheiden, te weten de onmiddellijke, de relatief onmiddellijke of relatief middellijke, en tot slot de middellijke rechter. In éen strafzitting kunnen de verschillende typen zich bovendien op onderdelen wisselend manifesteren. De kwalificatie wordt bepalld door de frekwentie en door het belang van de wijze van functioneren.

Kenmerkend voor het eerste type is de orientatie op de rechtshandhaving. De daarmee gepaard gaande kritische distantie ten aanzien van het opsporings- en vervolgingsapparaat biedt rumte voor controle op het voorbereidend onderzoek, en met name ook op de vervolgingsbeslissing door het Openbaar Ministerie. Er is gegeven de ruime mogelijkhe-

Gelet op de persoon van de rechter, WODC rapport 58 , "S-Gravenhage 1985, en de bespreking darvan door G.A.A.J. van den Heuwel in NJB 1986, p. 69-72 onder de titel: De persoon wan de rechter. Een overzicht mat aanleiding van recent Mederlands ondirack.

1 Het verschinsel wan de anonieme getuige is in de theorie en praktijk war de strafrechus pleging terech bred uitgeneten. Voor en kritish overzicht wotdt verwezen nat A.H.j. Swant: Anomeme getuigen en eem lijk proces, in: Recht als nom en aspiratie, Nijmegen 1986, p. 348-378, en na de publicatie van het rapport van de Europese Commisse, inz. Kostovskistaat der Nederlanden, mei 1988. G. Molsen T. Spronken: Anomieme getmigenverklaringen in strafzaken aan banden gelegd, ir: NJB, r988, p. 


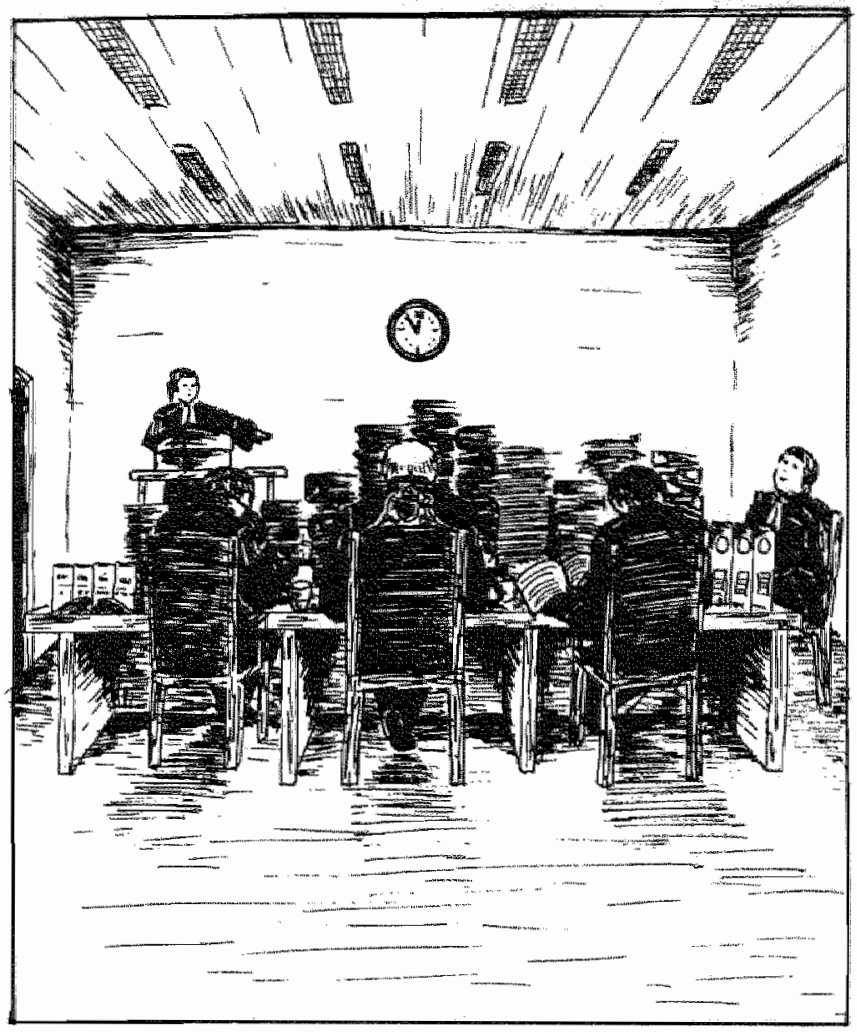

den voor buitengerechtelijke afdoening van strafzaken alles voor te zeggen de beslissing om de zaak ter zitting aanhangig te maken, aan controle te onderwerpen. Immers de afdoening via de strafrechter wordt in het algemeen nog als de meest vergaande wijze van afdoen gezien, en gelet op de andere voorhanden zijnde modaliteiten zou de onmiddellijke rechter het initiatief kunnen nemen via de interne en externe openbaarheid een begin van controle op die beslissing mogelijk. te maken. ${ }^{12}$ Darmee wordt aansluiting gezocht bij het ambtshalve bevolen onderzoek naar aanleiding van het dossier of de behandeling ter

12. Gegeven de mogelijkheden ale het Openbar Ministerie ter beschikking statu om strafzaken af te doen, is in toenemende mate de vragg gerechtvalardigd warom een zak ter zittionganhangig is gemaakt en net volgens en butengerechtelijke nodaliteit is afgedan. De afdoening via de rechter worde als de meest normale, althans zodanig voor de thand liggend beschouwd dat een motivering darvoor achterwege wordt gelaten. War het aanbrengen ter zithing cerder utzondering dan regel lijk "dient de beslissing ook overenkomstig gemotiveerd, inzichtelijk en controleerbaar te zijn. 


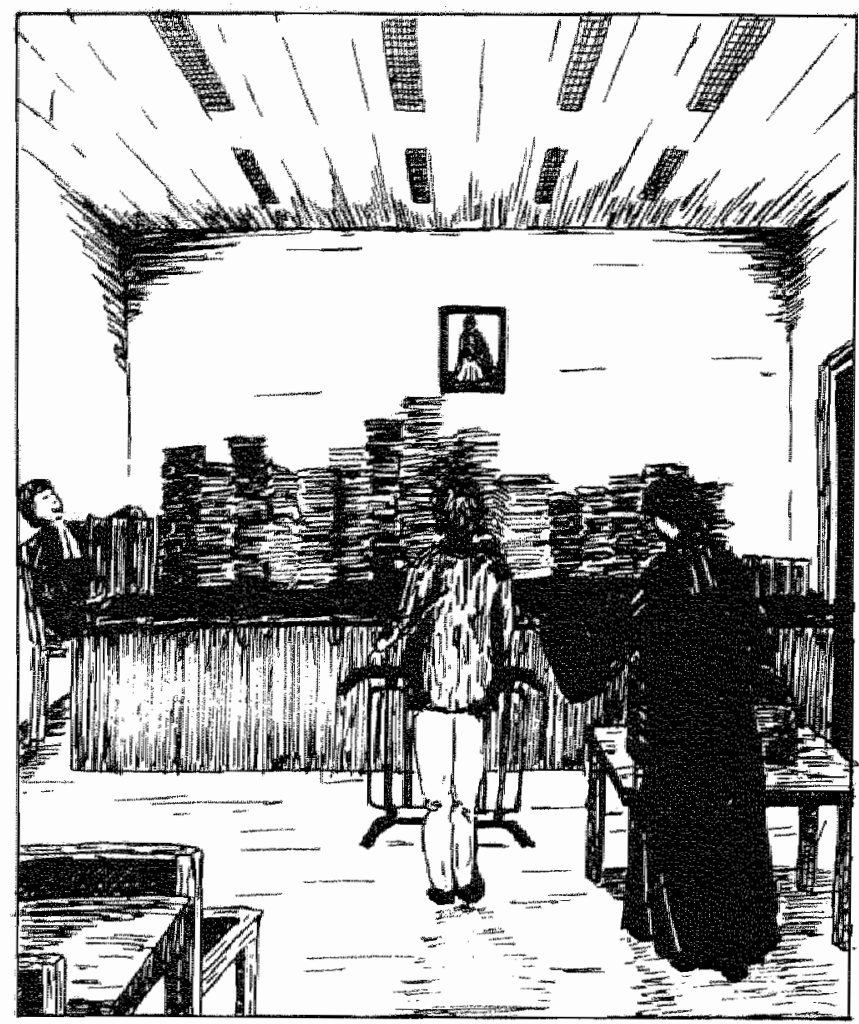

zitting. In het model warin het confrontatiebeginsel gerealiseerd wordt vindt een opwaardering van het eindonderzoek ter zitting plaats. De zittingen zijn levendiger, maar duren ook langer. Essentiëler is echter dat het debat over het bewijs mogelijk wordt, en daar gevoerd wordt waar het thuishoort, namelijk voor degene die moet beslissen. Het voorbereidend onderzoek wordt wat het behoort te zijn, nl. voorbereidend.

In de praktijk van de strafrechtspleging overheerst het tweede type, de relatief onmiddellijke of relatief middellijke rechter. Kenmerkend is de neiging on de criminaliteitsbestrijding als hoogste doel wan het strafproces te zien. Daamee gat een minder kritische distantie ten anzien van het opsporings-en vervolgingsapparat gepaard. Veeleer wordt de rechtspraak van dit type rechter gekenmerkt door ten a priori vertrouwen in justitie en politie, dat slechts dan en in voorkomende gevallen nog slechts met moeite, ter discussie wordt gesteld wanneer een misslag 12 evident is, ambeshalve, en op verzoek wanneer de verdediging anvoert 
dat het bewijs op onrechtmatige wijze is verkregen. De controle op het voorbereidend onderzoek is dan minimaal. Ter zitting gebeurt bovendien weinig wezenlijks. $\mathrm{Er}$ is weliswaar sprake van een mondelinge behandeling, maar de stukken zijn tevoren grondig bestudeerd en worden bekend verondersteld. ${ }^{3}$ Het voorhouden van stukken gebeurt soms bij wijze van surrogaat uitgebreid, soms zeer summier, en in voorkomende gevallen wordt gesuggereerd dat het voorhouden zeker wel achterwege kan blijven omdat betrokkenen de stukken wel bestudeerd zullen hebben. Kenmerkend in dit model is de functie van de rechter-commissaris als toevluchtsoord om getuigen heen te verwijzen wanneer het aantal het getal twee overschrijdt. Getuigen worden namelijk bij voorkeur niet ter zitting gehoord. Dat kost tijd en daar is met de appointering geen rekening mee gehouden, tenminste wanneer het om getuigen gaat die op verzoek van de verdachte op de lijst van getuigen zijn geplaatst. ${ }^{14}$

Een negatief verklarende factor hiervoor is wellicht de afwezigheid van een wettelijke verplichting om de getuigen ter zitting te horen, zoals die in sommige buitenlandse rechtsstelsels bestaat. Op praktisch niveau is het meest gehoorde argument dat men simpelweg niet inziet de noodzaak nog eens over te doen wat al door de opsporingsambtenaar is gedaan.

Het middellijke type tenslotte, kenmerkt zich door een zuiver inquisitoire inslag tengevolge waarvan ruim baan wordt gemaakt voor een direkte doorwerking van het opsporingsonderzoek in het eindvonnis zonder kritische toetsing tijdens het eindonderzoek. Hier is het politionele aspect in het eindonderzoek dominant, en wel zodanig dat het onderscheid met het geheime schriftelijk proces vervaagt.

In het spanningsveld tussen enerzijds de realisering van het onmiddellijkheidsbeginsel als juridische wens en anderzijds de snelheid en doeltreffendheid van het strafproces als organisatorisch verlangen, is het

3 In het tevoren bestuderen van het dossier schuilt een groot gewar voor het onmiddel. lijkheidsbeginsel vanwege het risico van wooringenomenheid van de recher. Zie in dit verband A.L. Melai: De onbewangen strafrechter, in DD 1979. p. 124-127.

*4 Getuigen die op initiatief van het O.M. worden gedagvard zijn bij de appointering bekend en derhalve kan daarmee rekening worden gehouden bij de planning wan de zituring. 
gebruik on ter zitting geen getuigen te horen van uitzondering tot regel geworden, en is het onmiddellikheidsbeginsel van zijn confrontatiepretenties ontdaan. Er schijnen rechtbanken te zijn war helemal geen getuigen meer ter zitting worden gehoord, onder het motto: de rechtbank heeft wel wat beters te doen. ${ }^{15}$ Voor alle duidelijkheid: ik ben van mening dat het juist de taak van de rechter is om een zelfstandig onderzock in te stellen en persoonlijk kennis te nemen van het bewijsmaterial tijdens het onderzoek ter terechtzitting. Juist bij het bewijs door middel van getuigen is die persoonlijke confrontatic van eminent belang, terwijl bovendien de procespartijen dan in de gelegenheid zijn om te participeren in het wartheidsvindingsproces. Ik bepleit dan ook het horen van getuigen ter zitting als principe, waarop in woorkomende gevallen uitzonderingen mogelijk zijn. Dit uitgangspunt vloeit rechtstreeks woort uit de hiervoor genoemde drie aspecten wan het onmiddellijkheids - of confrontatiebeginsel en kan nader worden onderbouwd

${ }^{3}$ Onderstand persbericht wit de Limburger van 16 februar 1989 geeft een getrouw beeld van de siruatic die ontstat wanneer de verdachte verzoekt om een groot aantal getuigen ter zituing te horen. Gegeven dhe organisatie van de strafrechtspleging on de beperkte omvang van de rechterlijke macht is de reaktie wan de woorzitter van de strafkamer begrijpelijk, hetgeen de beslissing on het verzoek in te willigen op grond van de overweging dat een fundamenteel recht in het geding is, des te prijzenswaardig maker.

\section{Verdachte staat op recht Rechtbank hoort 12 getuigen in het oponbaar}

Van onze verslaggefstet

MAASTRICHT

rechtbank Miasstricht gaat op 13 maart in een openbare rechtsalttilng 12 getulgen horen. De rechtbank doet dit op verzoek van een 39 -jarige Heerlenaar dle verdaobs wordt van handel in heroine. dachte tevergeefs op de De Heerlenaar stond er enorme werkdruk van gisteren op dat alle man- rechters. "U kunt net zo men en vrouwen die tegen goed de burgemeester hem belastende verkla - van Maastricht laten koringen hebben afgelegd men om te kijken of het in het openbaar aran de adres nog well klopt Wij tand worden gevoeld. Hij hebben werkelijk wel wil dan zelf ook vragen wat anders te doen. Laten stellen.

Zo'n uitgebreid verhoor ven".

door de rechtbank is de De verdachte hield woet laatste jaren niet meer bij stuk. En de rechtbank gebruikelijk. Het kast kwam tot de slotsom dat weell tijd. De rechtbank de verdachte om een funverwijst meestal terug damenteel recht vroeg en naar de rechter-commis- zag geen mogelijkheid om saris, die de getuigen bui- het werzoek af te wijzen. ten de openbaarheid ver- De Heerlenaar wordt hoort.

verdacht van de handel

Rechtbankpresident $\mathrm{mr}$. in enkele honderden 1. Nolet wees de ver-grammen heroine. 
door kennisneming van de resultaten van forensisch-psychologisch onderzoek.

\section{Horen van getuigen}

Het gebruik van processen-verbaal van verhoor van getuigen in plaats van het horen van de getuigen zelf doet afbreuk an een gemotiveerd oordeel over de kwaliteit en de betrouwbarheid van de getuigenverklaring. De rechter die een getuige niet zelf heeft gezien en gehoord kan zich nauwelijks een gefundeerd oordeel aanmeten over de vraag of de getuige wel of niet betrouwbaar is. Door op stukken recht te doen geeft de strafrechter een deel van zijn primaire functie prijs en legt dat in handen van degene die de verklaring op schrift heeft gesteld. Dat is in de regel een opsporingsambtenaar, van wie niet gezegd kan worden dat hij geen belang heeft bij het zo spoedig mogelijk rond krijgen van een zaak, en wiens taak het is te werken vanuit de psychologische vooronderstelling van schuld bij de verdachte. Van daaruit ook formuleert hij zijn bewijsargumenten in het proces-verbaal. Zelfs wanneer wordt aangenomen dat de desbetreffende ambtenaar volkomen te goeder trouw heeft gehandeld en zelfs wanneer er geen indicaties zijn dat aan de betrouwbaarheid van de getuigenverklaring getwijfeld moet worden, dan nog blijft het in het licht van de waarheidsvinding problematisch om op stukken recht te doen. Deze benadering gaat er immers aan voorbij dat een getuige volkomen te goeder trouw onwarheid kan vertellen, bijwoorbeeld omdat in zijn geheugen informatie is opgeslagen waarvan niet meer kan worden achterhaald uit welke bron die informatie stamt, maar die door de getuige te goeder trouw wordt gepresenteerd als zijnde door hem waargenomen. Denkbaar is echter dat derden de getuige na het woorval die informatic hebben verstrekt. In dit verband wordt de politie een belangrijke rol toebedeeld. . $^{\text {ti }}$ Tijdens

16 Zie bijvoorbecld $\mathrm{C}$. Nagler. Vernehmungspsychologie: Wartum Personen sich bei der Vernchmung nicht andas erinnern können was sie wissen, in: Strafvertcidiger, $5 / 1983$, p. 21 e v. Hij metkt over de rol van de politic ten aanzien wan het thema fictie ws werkelijkheid (Menung versus tatsächliche Wahmehmung') letterlijk het volgende op: "Ein nicht 2u unterschäzender Fakior bei dieser Meinungsbildung sind die of mehrfach durchgefuhrten polizeilichen Vernehmungen, bei denen sin ganz bestimmtes Ermitungsinteresse der befragenden Beamten Art und Umfang der von hinen 
verhoren kan zij door wragen te stellen en door de getuige informatie woor te houden de getuige beinvloeden en wel zodanig dat de getuige als waar reproduceert wat hij in werkelijkheid van de verhorende ambtenat vernomen heeft.

Getuigen zijn mensen die fouten kunnen maken, al dan niet bewust. Men moet echter bedenken dat een getuigenverklaring van beslissende betekenis kan zijn voor de uitkomst van het strafgeding. De verdachte heeft er recht op dat uiterst zorgvuldig en kritisch met getuigenverklaringen wordt omgesprongen. Dat dat niet altijd het geval is heeft de Bolderkaraffaire geleerd. ${ }^{17}$ In die zaak was het nogal duidelijk dat verklaringen van kinderen, zeker wanneer ze tot stand zijn gekomen met hulpmiddelen als poppen, uiterst dubieus zijn vanwege de suggestie die van de gebruikte poppen uitgaat, en de vermenging van fictie en werkelijkheid, welke vermenging door een leek op het terrein van de forensische-psychologie niet kan worden uitgefilterd. ${ }^{18}$ Inmiddels lijkt besloten te zijn om minderjarigen zo mogelijk nog slechts door daartoe gekwalificeerde personen te laten horen. ${ }^{19}$ Dat laat overigens onverlet dat het nodig is ook dan controle uit te oefenen.

gestellen Fragen und damit auch implizit Art und Umfang der Erinnerungsleistung und deren Darstellung durch den Zeugen/Angeklagten beeinfussen kann. Auf Fragen vor Gericht erinnert der Vernommene nicht, mehr wirklich das, was er geschen und gehört hat, sondern das, was er $2 u$ dem Gesehenen und Gehörten in der $Z$ wischenzeit gesagt und gedacht hat. Und dies tut er in besen Glauben, dic Wahrheit za sagen'.

17 In dic zaak die zijn nam ontleent aan de namgeving wan het $\mathrm{M}(\mathrm{cdisch}) \mathrm{K}(\mathrm{leuter})$ D(agverblif) De Bolderkar te Vlaardingen war de zaak aan het rollen kwam en de onderzoken werden werricht, ging het om wermocdens van ontucht met minderjarigen welke vermoedens ontstonden althan werden onderbouwd met werklaringen wan de minderjarigen afgetegd in ecn werhoorsiwatie warin de zgn. poppenmethode werd gehanterd. Bij deze methode wordt gebruk genak

if De betrouwbarheid van de poppenmethode is in rechte an de orde gesteld in ecn zaak warin de Hoge Rad bij atrest van 28 febr. 1989, nr. $84.723 \mathrm{cen}$ arrest van het Gerechthof Amsterdam vernerigde angezien de bewezenverklaring niet nat de eis van de wer was gemotiveerd. Het Hof had namelijk zonder motivering woor het bewijs gebruik gemakt van de resultaten wan een onderoek met de poppenmethode, terwij] de radsman de betrouwbarheid van die methode in twijel thad getrokken en op basis van die twijfel had werzocht on een onderzoek door terzake desundigen. Dat vond het Hof met nodig, en achte zich voldoende voorgelicht.

14 Aldus en bericht in NRC-Handelsblad van 3 mant 1989 onder de kop: Opleiding van politic voor werhoor kind. 
De bijzondere behandeling van de minderjarige als getuige valt de meerderjarige getuige nog niet ten deel. Dat will uiteraard niet zeggen dat het verhoor van meerderjarige getuigen minder problematisch is.

Bij de torstandkoming van een getuigenverklaring kumnen een drietal stadia worden onderscheiden, namelijk de fase van de waarneming, die van het geheugen en de herinnering, en tot slot de fase van de reproduktie. ${ }^{20}$ Bij de warneming kunnen zich factoren voordoen die de warneming bevorderen of juist belemmeren. Die factoren kunnen gelegen zijn in de omstandigheden waaronder wordt wargenomen, zoals bijvoorbeeld licht of duisternis, of goed zicht of mist. De factoren kunnen ook betrekking hebben op de gebeurtenis zelf die wordt waargenomen. Bijvoorbeeld herhaalt het gebeuren zich, of was het slechts eenmalig en bovendien van korte duur? Tot slot kunnen de omstandigheden kleven aan de persoon van de getuige. Is thet iemand die rustig observeert, of was de getuige ten tijde van de waarneming bang en vooral op zoek naar een vluchtweg? Verwachtte de getuige een bepaalde gebeurtenis, of voltrok hetgeen hij waarnam zich plotseling en was de getuige er niet op voorbereid? De omstandigheden waaronder werd waargenomen, de manier waarop het gebeuren zich heeft gemanifesteerd en de persoon en diens psychische en fysieke gesteldheid zijn van belang voor de beoordeling van de vraag of de getuige gezien heeft wat hij zegt te hebben gezien. Een voorbeeld: de getuige zegt een aanrijding te hebben gezien. Hij zag namelijk twee auto's krachtig remmen, dicht op elkaar tot

Zie over de minderjarige als getuige o.a. F. Arntzen: Vernehmungspsychologite: Psychologie der Zeugenvernehmung, München 1978, p. 34 e.v.;

W.A. Wagenar: Kinderen in geruigenbank blijken heel vatbar voor suggesties, Volkskrant, 18 juni 1987 .

Zie voort John Nigel Pepper: The Child Winess, in: Criminal Law Quarterly, 1984, p. $354-384:$

Christa Gley: Psychologische Grundlagen und Kriterien der Beurteilung won Zeugenaussagen bei Kindern und Jugendlichen, in: Strafverteidiger, 9/987. p. 403-410, Nancy W. Pery an Larry L. Tepley. Intervicwing. Combeling and inw Court examuation of chidren: practical approaches for attomeys, in: Creighton Law Review $1984 / 85, \mathrm{p}$. $1369-1426$.

20 Hicrover uitgebreid o.a. Marcus Stonc: Proof of Facr in Criminal Trials, Edinburgh 1984

Norbert L. Kert, Robert M. Bray (cds.): The psychology of the Courtroom, New York 1982; $\mathbb{E}$, Loftus: Eyewitness Testimony, Cambridge 1984. 
stilstand komen, en vervolgens twee mannen uitstappen die hevig gebarend op elkaar toelopen, agenda"s trekken en notities maken. De getuige ziet een anrijding, in werkelijkheid was er sprake van een ontmoeting van twee bekenden van elkaar die mekaar lange tijd niet hebben gezien en een afspraak maken. ${ }^{21}$

De tweede fase is die van het geheugen. ${ }^{22}$ Algemeen bekend is dat de herinnering door enkel cijdsverloop vervaagt. Men kan zich na enige tijd bepaalde gebeurtenissen niet meer herinneren. Wezenlijker is echter dat het geheugen vervormd kan worden door informatie die er na de waarneming wordt bijgestopt, en die de originele beelden kan vervangen. Mensen creëren ketenen van causaliteit die vaak niet overeenstemmen met de werkelijkheid. Zoals gezegd kan dat door bijwoorbeeld gesprekken met derden, door het lezen van kranten, en door het voorhouden van informatie tijdens een verhoor. ${ }^{23} \mathrm{Het}$ is derhalve zaak zo mogelijk te reconstrueren waar de getuige de informatie vandaan heeft zodat een onderscheid kan worden gemaakt tussen fictie en werkelijkheid.

De derde fase is die van de reproductie. De getuige wordt gevraagd weer te geven wat hij heeft waargenomen. De reproductie komt tot stand hetzij spontaan, hetzij naar aanleiding van vragen, zonodig aangevuld met het verstrekken van informatie met het verzoek daarop te reageren. Het moge na het voorgaande duidelijk zijn dat het aanbeveling verdient om de getuige vooral in de gelegenheid te stellen om zijn eigen verhaal te vertellen. Het voorhouden van informatie kan de getuige beinvloeden, maar ook het stellen van vragen kan van invloed zijn op wat de getuige verklaart. Onderzoek heeft uitgewezen dat getuigen eenvoudig te beinvloeden zijn door het stellen van in meerdere of mindere mate suggestieve vragen. ${ }^{24}$ De vraag of de verdachte het pistool in zijn rechterhand had, is een suggestieve vraag die in veel gevallen een bevestigend antwoord uitlokt ook al had de verdachte het pistool in zijn linkerhand, en zelfs als de verdachte helemaal geen pistool had. Aan de vraag dienen ten minste twee vragen vooraf te gaan: heeft u

21 Het voorbeld is onteend a an certinstructie-videoband Observeren dl. I en 2 , Skillshb Medische Faculteit RI Mastrickn.

23 Stewen Penrod, Elizabech Loftus, John Winkler: The Reliability of Eyewimess Testimony: A psychological Perspective, in: Norbert L. Kerr, a. W., p. I19-168.

23 Idem.

24 1 dem. 
een pistool gezien? Had de verdachte het pistool? Vervolgens: Heeft u gezien of de verdachte het pistool in de hand had, en zo ja in de linkerhand of de rechterhand?

De beinvloeding van getuigen kan op uiterst subtiele wijze en vak onbewust gebeuren. Er kunnen bepaalde gewenste antwoorden mee worden uitgelokt. Wie wil dat een bepaalde film kort duurde zal vragen: Hoe kort duurde de film? Wie liever een wat langere tijdseenheid hoort zal de voorkeur geven aan de vraag: Hoe lang duurde de film?

Beinvloeding kan op minder subtiele manier plaatsvinden door bijvoorbeeld bij een fotoconfrontatie een bepaalde foto op een van de presentatie van andere foto's afwijkende manier te tonen, bijvoorbeeld schuin, of iets langer. Van beslissende betekenis kan ook zijn de vraag die voor de confrontatie aan de getuige wordt gesteld: Kunt u de verdachte aanwijzen?, hetgeen impliceert dat de verdachte erbij zit, of: Zit de verdachte hier volgens u bij?, hetgeen de mogelijkheid openlaat dat de verdachte niet tussen de foto's zit. De laatste vraag is de meest juiste. Zij laat de getuige vrij om iemand an te wijzen, meer dan bij de vraag of beter gezegd de opdracht de verdachte aan te wijzen. ${ }^{25}$ Het verdient aanbeveling on de getuige eerst geheel spontaan een beschrijving te laten geven van de persoon die hij heeft gezien om vervolgens de foto's te presenteren. Indien de getuige eerst bekend wordt gemaakt met het witerlijk van de verdachte of zelfs weet wie het is, dan is de fotoconfrontatie niet meer dan een test om te zien of de getuige in staat is een plaatje aan te wijzen waarop de kort tevoren meegedeelde kenmerken voorkomen: lange neus, krullend haar, etc. ${ }^{26}$ Er zijn voor de fotoconfrontatie richtlijnen voor de politie opgesteld die mar zelden worden nageleefd. ${ }^{27}$ Dat geldr evencens voor de meerkeuze- of Osloconfrontatie. ${ }^{28}$

${ }^{2}$ Zie over de fotoconfrontatie a.a. Robert Buckhout, Daryll Figueraa: Eyewitness Identification: Effects of Suggestion and Bias in Identifications from Photograplas. New York, 1974: Steven Penrod, a.w; Stone, a.w.

${ }_{26}$ Penrod, a.w. on W.A. W/agenaar tijdens zijn voordracht over "Psychologische achtergronden van ooggenigen" op her Jonge Balie Congres 1988: "Niets dan de warheid. Getuigenbewijs in civiel- on strafrecht:" Hejen 1988.

z Zie Henk Holrslag: Sporen onderzocht. Handboek recherchetechnick, Lelystad 19s6. p. $162-164$.

28. Henk Holtslag, a.w. p. 165-167. 
De daarvoor opgestelde richtlinen en de tengevolge daarvan ontstane bewerkeljkheid wan deze confrontatie doen de politie in de praktijk teruggripen op de confrontatie met de confrontatiespiegel warachter zich één persoon bevindt, meestal de verdachee. De vraag aan de getuige of hij de persoon herkent en het daaropvolgend antwoord kan nauwelijks serieus worden genomen, en met name niet wanner de getuige de verdachte na het gebeuren nog gexien heeft, en al helemaal niet wanneer de getuige is meegedeeld dat de verdachte is angehouden en de getuige hem nog slechts hoeft te herkennen.

Naast de te goeder trouw onwarheid vertellende getuige staat de willens en wetens liegende getuige, bijvoorbeeld vanwege een eigen belang bij een bepaalde uitkomst van het geding. Voorzover de onwarheid manifest is of door het opsporingsapparaat manifest is gemaakt, valt de getuige al vroeg door de mand. Mar meestal ligt het niet zo eenvoudig en bepaalt ook deze getuige mede de richting van het opsporingsonderzoek.

Nu rijst de vrag of de zittingstechter in staat is om met behulp van het dossier zich een gemotiveerd oordeel aan te meten over de betrouwbaarheid van de getuige en zijn verklaring. Met andere woorden, kan hij op grond van de getuigenverklaring en de overige inhoud van het dossier enige controle uitoefenen op het warheidsgehalte van de verklaring. Het antwoord kan niet anders dan ontkennend zijn. De processen-verbaal van verhoor van getuigen zijn in de regel gepolijste verklaringen warvan op voorhand duidelijk is dat de getuige het zo niet gezegd kan hebben. Voorzover oneffenheden of ogenschijnlijk minieme tegenstrijdigheden worden weggemasseerd, wordt in feite door degene die de verklaring optekent verklaard wat hij denkt dat de getuige heeft gezien. Maar zelfs wanneer deze massage niet al te veel afdoet aan de inhoud en strekking van de verklaring, blijft het voor de rechter onmogelijk zich een beeld te vormen van de omstandigheden waaronder is wargenomen, van de warnemings-en reproductiecapaciteit van de getuige, en van de persoon van de getuige. Van even groot belang is dat niet getoetst kan worden of datgene wat door de getuige volgens het proces-verbat is verklaard dat is wat hij heeft waargenomen, of bij latere gelegenheid aan de getuige is meegedeeld en vervolgens via het zgn. freezing effect zich in het geheugen heeft genesteld om van daaruit 
gereproduceerd te worden als eigen warneming. ${ }^{29}$ Evemmin kan worden getoetst of de getuige überhaupt wel de warheid spreekt. Ter zitring kan door middel van een confrontatie van de getuige met andere informatie, met tegenstrijdigheden, en met kritische vragen worden getest of de verklaring op warheid berust. Daar komt bij dat de nonverbale communicatie een beslissende betekenis kan hebben voor de overtuiging van de rechter. Een liegende getuige stottert, draait op zijn stoel, of begint te transpireren. ${ }^{30}$ In het dialectisch proces van warheidsvinding $k$ an de ruis van beinvloeding zo mogeljk worden gecorrigeerd en kan doorgaans een reeler beeld van de betrouwbaarheid van de verklaring worden verkregen. Het zou al een verbetering zijn wanneer de processen-verbaal van getuigenverhoor meer informatie zouden bevatten ower de vragen die zijn gesteld, over de persoon van de getuige, over de omstandigheden waaronder de warneming heeft plaatsgevonden, en over de omstandigheden waaronder het verhoor heeft plaatsgevonden. Die informatie is niet alleen onmisbar voor het geval de getuigen niet ter zitting kunnen worden gehoord. Zij is ook nodig om te kunnen beoordelen of het nodig is om bepalde getuigen nog ter zitting te horen. Deze aanpassingen kunnen echter niet in de plaats treden van de confrontatie ter zitting, al was het mar ondat in het dialectisch warheidsvindingsproces de procespartijen de gelegenheid moeten hebben om de getuige aanvullende vragen te stellen.

Tijdens het opsporingsonderzoek is niet alleen de equality of arms zoek, er vind took nauwelijks een kritische toets wan de betrouwbarheid van de getuigenverklaring plaats. De oriëntatie op het rond krijgen van de zaak domineert hetgeen zich onder andere manifesteert in het gebruik dat wordt gemakt van de onwetendheid van de burger als getuige. De rechtspositie van de getuige is in het algemeen al sterk onderontwikkeld. ${ }^{31}$ Het ontbreken van enige werplichting de getuige op zijn rechten te wijzen, zoals bijwoorbeeld het recht on te zwijgen, afgeleid wit het ontbreken van een spreekplicht in deze fase van het onderzoek, leidt

E. Loftus al.w.

w Zie voor een overzicht wan non-verbate communicatie: Gerald $R$. Miller, Judee $K$. Burgoon: Factors Afrecting Assessments of Witness Credibility, in: Norbert L. Kerr. a. W. P. I60-194:

"Over de rechtspositie wan de getuige in strafaken: Jens Roger Schmidt: Die Reche des Zeugen im Strafwerfahren, Inaugural-Dissertation, Nürnberg 1986. 
ertoe dat getuigen zelden erop wordt gewezen dat ze niet tot antwoorden verplicht zijn. Het gebruk maken van de on wetendheid van de doorsnee burger wreekt zich met name daar waar getuigen op enigerlei wijze nauw betrokken zijn bij de dader en/of de daad, of uit anderen hoofde bereid zijn een belastende verklaring af te leggen. In dit verband is het van belang te wijzen op de kennelijk gebruikelijke gang van zaken volgens welke strafzaken tegen mogelijke heroinedealers worden ingeleid. Er worden notoire druggebruikers van de straat opgepakt die op het buro aangekomen de status van getuige krijgen aangemeten en aldaar verzocht worden de of een dealer aan te wijzen. Zodra dat gebeurd is wordt de arrestant op vrije voeten gesteld en duikt onder in de massaliteit van de vrije samenleving. De getuige is dan doorgans niet meer te achterhalen. Dat weet de getuige ook, dus een verklaring is snel afgelegd zonder veel vrees voor represailles of voor een pijnlijke confrontatie ter zitting, en bovendien lijkt het alsof de arrestatic en eventuelle vervolging met een jegens een derde afgelegde belastende verklaring kan worden afgekocht.

Enkele van de hierwoor genoemde bezwaren gelden in mindere mate wanneer het verhoor plaatsvindt door de rechter-commissaris. Dat heeft in elk geval als voordeel dat het verhoor plaatsvindt voor en door cen rechterlijk orgaan, dat minder dan het opsporingsapparaat de schijn van belang bij een snelle afwikkeling tegen zich heeft. Bovendien kan bij het verhoor door de $\mathrm{r}-\mathrm{c}$ de raadsman aanwezig zijn. Het verhoor kan pas dan bij de realisering van hec confrontatiebeginsel in de buurt komen wanneer de raadsman t.a.v. de getuige dezelfde rechten toekomen als ter zitting $\mathrm{en}$ bovendien de verdachte in de gelegenheid is alle verhoren bij te wonen en vragen te stellen. Een van de aspecten van het onmiddellijkheidsbeginsel is nu juist dat de verdachte zich over het bewijs kan uitlaten in een directe confrontatie daamee. Het is een misvatting te denken dat de raadsman bij het getuigenverhoor de verdachte kan vervangen. De verdachte is nagenoeg bij elk getuigenverhoor onmisbar aangezien hij doorgaans beter dan de raadsman op de hoogte is van de feiten, en onjuistheden of oneffenheden in de verklaring van de getuige beter kan aan wijzen. Het lijkt overigens gegeven de prakrijk van de verhoren bij de $r-c$ buiten aanwezigheid van de verdachte, niet erg consistent om vervolgens de afwezigheid van de verdachte ter zitting aan te grijpen als regel om ook de radsman niet aan het woord te laten. 
Intussen kan het verhoor door de $\mathrm{r}-\mathrm{c}$ de confrontatie voor de zitringsrechter niet vervangen. Ter zitting kaw nog een en ander gebeuren waarover de getuige nog gehoord zou moeten worden; de indruk en overtuiging van de r-ckumen niet in de plaats treden van die van de zittingsrechter die uiteindelijk zal moeten beslissen; het onderzoek door de $r-c$ is in het licht van het totale strafproces te zeer fragmentarisch om als volledig onderzoek inclusief afgeronde betrouwbaacheidstoets te gelden, en tot slot zal de mogelijkheid moeten blijven bestaan voor de partijen om in een dialectisch proces anvullende vragen te stellen en opmerkingen te maken, en wel tegenover degene die de beslissing neemt. Daarmee rijst de vraag of alle getuigen ter zitting moeten worden gehoord.

\section{Alle getuigen ter zitting?}

Het onmiddellijkheidsbeginsel impliceert dat alle getuigen die voor het bewijs van belang zijn ter zitting worden gehoord. Onder handhaving van het uitgangspunt dat horen staande de zitting regel is, en dat uitzonderingen in de loop der jaren gegroeid slechts onder bijzondere omstandigheden acceptabel zijn, is een systeem denkbaar waarin het verhoor van getuigen wordt opgedragen an de rechter-commissaris of aan een van de zittingsrechters. ${ }^{32}$ Dat zou bijvoorbeeld het geval kunnen zijn bij bekennende verdachten. Denkbaar is ook dat partijen uitdrukkelijk en expressis verbis afzien van het horen van getuigen. Denkbaar is bovendien dat de verhoren van getuigen tijdens het voorbereidend onderzoek worden geaudiovisualiseerd. De van deze verhoren gemaakte banden maken deel uit van het dossier, worden met het dossier aan de procespartijen en de rechter ter beschikking gesteld, en kunnen ter zitting worden getoond. ${ }^{33}$ Deze audio-visualisering binnen het straf-

32 A.J.M. Machiclse bepleir de mogelijklyeid van verwijzing naar een wain de zitungstechtets, in: Een requiem woor het gerechelijk vooronderzock, oratio Nujmegen 1989 .

33 Men zou met de awdio-visualisering wan (onderdelen vanj het strafproces nog verder kunnen gaan dan alleen het voorbereidend onderzoek. Ook bet eindonderzock zelf zou kunnen worden vasigelegd op film hetgeen de woobereiding vam appel en cassatie aanzienlijk zou kunnen vereenvoudigen en verangenamen. Voorzoven het verhoor van getuigen en verdachten in de voorbereidende fase word opgenomen, is ex sprake van besparing van kosten en tijd. De processen-verbaal zodden kunnen worden 
proces die naar mijn mening te veinig wordt gebruikt, verlevendigt niet alleen de voorbereiding en onder de bestaande condities ook het eindonderzock ter zitting, voor wat betreft de getuigenverhoren kan enigermate inzicht worden gegeven in de wijze waarop de getuige eerder is verhoord. Met de omkering van de regel dat ter zitting geen getuigen worden gehoord tenzij... wordt tegengegaan dat het vooronderzoek naadloos overgaat in het eindonderzoek waarbij niet de rechter maar de opsporingsambtenaar in feite de uitkomst van het strafproces bepaalt, en dat is in strijd mot de fundamenten van het rechtsstatelijk strafproces waarin de onafhankelijke rechter toetst en beslist. Een verdergaande relativering van het beginsel dan hiervoor aangegeven namelijk in geval wan en bekennende verdachte, en bij uirdrukkelijke instemming van de procespartijen, benadrukt het politionele karakter van het strafproces en vormt een vruchtbare bodem voor misbruik die het beste gedijt in een overwegend schriftelijke en geheme procedure. Het onmiddellijkheidsbeginsel beoogt onder andere dat tegen te gaan. Gegeven de huidige ontwikkelingen warin een versterkte tendens tot geheimhouding en anonimiteit valt wat te nemen, met uitzondering van de anonimiteit van de verdachte, wint het confrontatiebeginsel aan betekenis en verdient elke poging tot relativering ervan extra aandacht. vanuit het perspectief van het rechtsgehalte van de strafrechtspleging.

\section{De geheimhouding in het strafproces}

In onze strafrechtspleging komt zoals opgemerkt vooral het relatief onmiddellijke type zittingsrechter voor dat in voorkomende gevallen een sterke neiging vertoont zich te willen transformeren in het middellijke type warvan geheimhouding en anonimiteit de bijzondere kenmerken zijn. Het strafproces lijkt in toenemende mate beheerst te worden door geheimhouding waarbij de rol van de rechter geminimaliseerd is onder gelijktijdige versterking van de positie van het opsporings- en vervolgingsapparaat. Bepaald zorgwekkend is de relatieve eenvoud warmee de absolute afwezigheid van de confrontatic in de

vervangen door de videoband, veel rypewerk kan acherwege blijven, en het verhoor guat wele mallen sneiller. 
rechtspraak is geaccepteerd. Daaruit zou kumen worden afgeleid dat ons hoogste rechtscollege zich weinig gelegen lat liggen an op zichzelf gerech tvardigde verlangens tenminste het eindonderzoek in strafzaken een zeker contradictoir cachet te geven. Het verschïnsel van de anonieme getuige is een vanuit het confrontatiebeginsel gezien voorlopig dieptepunt. Maar ook bij de geldende praktijk van het niet horen van getuigen ter zitting kan toch moeilijk ontkend worden dat wezenlijke vragen onbeantwoord blijven: heeft de getuige wel waargenomen wat hij zegt te hebben waargenomen? Was de getuige wel psychisch en fysiek in staat om iets waar te nemen, en hoe staat het met zijn geheugen en reproductiecapaciteit, met de beinvloeding door derden, met het freezing effect, en met de belangen van de getuige bij een bepaalde uitkomst van de zaak? Is de getuige anoniem, dan is het evident dat deze in feite de uitkomst van de strafzaak bepaalt en is de rol van de rechter gemarginaliseerd, en de zitting gereduceerd tot een verplicht nummer waaraan nauwelijks enige legitimiteit ontleend kan worden. De volledige afwezigheid van enige vorm van confrontatie kan niet gecompenseerd worden door de mededeling van de $r-c$ of de politie dat de getuige wel betrouwbaar overkwam. De betrouwbarheid moet in de eerste plaats worden vastgesteld door degene die de beslissing neemt tweede plaats moet de betrouwbarheid blijken uit hetgeen door de getuige in een confrontatie wordt verklaard, alsmede uit de afwezigheid van factoren die op het tegendeel duiden. Dat laatste wordt niet onderzocht en komt dus niet aan het licht.

De anonieme getuge bevindt zich in gezelschap van de under-cover agent, de agent provocateur en de informant. Deze bijzondere opsporingstactieken kenmerken zich vooral door geheimzinnigheid en anonimiteit. Werd als ratio voor het niet prijsgeven van de identiteit van een getuige opgegeven de vrees voor represailles en het daarmee samenhangende gevaar dat door gebrek an bewijs zaken niet meer met succes konden worden vervolgd, de Hoge Raad accepteert de anonieme getuige ook in het belang van het opsporingsonderzoek. ${ }^{34}$ Een under-

34 Zicom. HR 7 febr. 1989. nr. 84788. In die zak werd de identiteit wan leden van het in de destrerrefende zak opgetreden observaticteam nier prijsgegeven en werden zij als anoniame getuigen geintroduceerd. Het Hof overwoog dat het horen zonder de identiveit te wermelden noodzakelijk. was in verband met nadere vervulling van hun functie. De Hoge Raad besliste dat die reden ande toelaatbarlheid van het bezigen wan die werklaringen voor het bewigs niet in de weg stat. 
cover wordt onbruikbar als hij zijn identiteit prijsgeeft. Hij kan niet meer worden ingezet, hetgeen als voldoende is aanvaard om zijn identiteit te beschermen.

Men kan zich afvragen of en zo ja voor hoe lang deze argumentatie op gaat. De keuze voor het opsporingsbelang in de afweging van belangen geeft aan dat de Hoge Rad van oordeel is dat het onmiddellijkheidsbeginsel in zijn volle omvang kan wijken voor het toekomstig belang van een opsporing, waarmee bevestigd word dat het beginsel voorwerp is van criminele politick. Uit oogpunt van een rechtsstatelijk strafproces is deze beslissing vanwege de expliciete onmogelijkheid van rechterlijke controle op de executieve minder begrijpelijk. De motivering kan overigens niet altijd onverkort gelden. Under-cover agents zijn slechts gedurende een beperkte tijd inzetbaar, en er komt een moment dat ze met hun latste aktie bezig $2 i j n .{ }^{35}$ In dat geval gaat het argument van de bescherming ten behoeve van de inzetbaarheid woor toekomstige akties niet meer op. In voorkomende gevallen zal het Openbaar Ministerie moeten kunnen aangeven hoe lang de desbetreffende agent al undercover is, en wanneer zijn bijzondere status afloopt. Denkbaar is dat de behandeling van een concrete strafzaak dat moment afwacht. Denkbaar is ook dat in de afweging tussen de diverse belangen de overheid gehouden is ten behoeve van de realisering van het confrontatiebeginsel under-cover aktiviteiten te concentreren en te beperken zodat de anonimiteit ten behoeve van het strafproces kan worden opgeheven.

Een ander in dit verband slechts te vermelden verschijnsel is dat van de telefoontap. ${ }^{36}$ Ook hier gaat het om een geheime aktiviteit, waarvan degene die het betreft nooit weet hoeft te hebben. De indruk bestaat dat

35 Vgl. net wetslag valn de studie bimen lnet Openbar Ministerie over infiltratic als opsporingstechnick, opgenoman in dr Sedatscourant 230,4 december 1985 . Zie ook $\mathrm{F}$. Herog, Rechustaatliche Begrenzung der Verbrechersbekampfung. Ene kritische Bilanz der höchstrictuerlichen Rechsprechung zun Taprowozierenden Einsatz polizeilichor Lockspitzel, in NStZ 1985. 4, p. 15.3 e.v.

Wh Zic Egb. Myjer: Een getapt man, in: Bij doze stand van zaken, Bundel opstellen angeboden an A.L. Melai. Arrhem 1983, F. 313-324. Recentelijk H. Abbink en D. Vermunt: Telefoontap in NN-gvo, in Adv, B1. 1989, p. 142. 
van dit instrument op grotere schaal gebruik wordt gemaakt dan toelaatbaar is. ${ }^{37}$

Geheimhouding en verklikkerij gaan vaak samen en liken te worden geinstitutionaliseerd door een voortdurend inschakelen wan burgers bij de opsporing van strafbare feiten, waarbij vertrouwelijke behandeling van de verstrekte informatie in het vooruitzicht wordt gesteld. Voorlopig spant het nationale rechercheprogramma 'Opsporing verzocht' de kroon, door in nagenoeg elke vitzending warin meer of minder emstige delicten worden gepresenteerd de burger op te roepen medewerking te verlenen en informatie te verschaffen, waarbij de toegezegde vertrouwelijke afhandeling niet anders kan worden uitgelegd dan als bescherming van de identiteit van de burger in ieder geval tegenover de verdachte. Er zijn veel redenen waarom het programma zou moeten verdwijnen. Een ervan is dat het bijdraagt aan een cultuur waarin het gewoon is in anonimiteit te klikken. Het schuurtje van de buurman tijdens de Heyn-ontvoering is in dit verband spreekwoordelijk. ${ }^{38}$

Het zou dienstig zijn indien een nader onderzoek zou plaatsvinden naar de juridische juistheid en de maatschappelijke wenselijkheid van de

37 In dit verband is het aardig te vermelden dat op 18 februari jl. in het Dagblad De Limburger een bericht verscheen warin melding werd gemaakt van het opereren in Limburg van een zestal criminele organisaties die o.m. met behulp van telefoontaps in de gaten werden gehouden. Majoor Kuppens van de Rijkspolitie: 'De zware misdaad heeft woor ons prioniteit. We zijn op de hoogte. We luisteren telefoons af en werken met informanten die betaald krijgen.' Justitie ontkende een week later volgens hetzelfde dagblad het bestaan van die organisaties. Daarmee rijst de vraag op grond warvan de politie telefoons afluistert.

${ }_{38}$ Tijdens de Heijn-ontwoering heeft de politie zich bediend wan een woordvoerder die zich o.a. via de televisie na het opheffen wan de informatiestop tot het Nederlandse publick wendde met het verzoek om infortwatie die kon bijdragen tot de opheldering van de ontvoering. $N$ a de anhouding van de inmiddels veroordeelde verdachte liet de woord voerder weten dat hij door het Nederlandse publiek overstelpt was mitt tips, en voegde er aan toe dat wanneer gevraagd zou zijn om eens een kijkje te nemen in het schuurtje van de buurman, de Nederlandse burger dat ook gedaan zou hebben. Ik vrees dat hij gelijk zou hebben gekregen, hetgeen nog enn bewestigt hoe voorzichtig en terughoudend de overheid dient te zijn bij het inschakelen van burgers in strafzaken, mede gelet op de betrekkelijk geringe bijdrage die de duizenden tips hebben scleverdl aan de ontknoping van deze ontwoering. Zie hierover ook mijn bijdrage in het Crimineel Jaarboek van de Coornbert Liga, Breda 1989: Overheid en pers in de Heijnontvocring. 
in het vooruitzicht gestelde vertrouwelijkheid van door burgers an de politie verschafte informatie.

De voortschrijdende anonymisering van het strafproces als een van de resultaten van de relativering van het confrontatiebeginsel tast de openbaarheid in emstige mate aan, en maakt controle op justitiele aktiviteiten moeilijk zo niet onmogelijk. Achter de regelmatig in processen-verbaal opduikende zinsnede 'blijkens binnengekomen ambtsberichten' kan een argeloze informant schuilgaan, maar evengoed een onrechtmatig handelende opsporingsambtenar.

De geschetste ontwikkeling kan in de nabije toekomst een aantal belangrijke impulsen verwachten. Daarom zou ik willen bepleiten dat het des te noodzakelijker is vast te houden an de realisering van het onmiddellijkheidsbeginsel in al zijn facetten en te bestrijden dat crimineel-politieke overwegingen van beslissende betekenis worden voor de $\mathrm{k}$ waliteit van de strafrechtspleging.

Het verdwijnen van de binnengrenzen in Europa, eerst binnen het Schengengebied en vervolgens bimnen het territorium van de EEG, zal leiden tot cen vergaande mate van politieke samenwerking, warbij niet alleen de opsporing van strafbare feiten maar ook het uitoefenen van controle op het doen en laten van individuele en van groepen van burgers een belangrijke aktiviteit wordt. ${ }^{34}$ Dit wordt mogelijk gemaakt dankzij computergestuurde informatieverwerking. Daarmee krijgen de strafvorderlijke bevoegdheden een kwalitatief andere invulling, waarbij

3" Het Schengenakkoord is gepubliceerd in Tractatenblad 1985, nr. 102. In de onderhandelingen dic op basis wan het akkoord worden gewoerd om uiteindelijk tot opheffing wan de binnengrenzen in het Schengengebied te komen, is het Schengen-informatiesysteem (\$1S) geintroduceed. Met behulp van dit computergestuurde systeem kan informatic worden opgevragd ower de status on het mogeljk criminele werleden van diegenen die zich binnerl het Schengenterritorium bevinden. Immers, "en goede informaticuirwisseling... is de hoeksteen van de internationale samenwerking bij de bestrijding van internationale of grensoverschrujdende criminalliteit". (Twesde Kamer, $1985-1086,19326, n \pi, 1$, p. 6). Overigens heef de cenwording van Europa niet zoveel witstande met de vergaande internationale samenwerking op het terein van de bestrijding wan internationale en grensoverschrijdende criminaliteit. Opvallend is verter hoe weinig andacht lijkt te worden besteed in het Schengen-overleg an de positic van de burger, de verdachte, en zujn verdediging. VIg. in verband met de computerisering van informatie ook K. Rebmann: Elektronische Datemverarbeitung (EDW) in Strafverfolgungsangelegenheiten tund Darenschutz, in: NSZ 1984, 1, p. I a. 
de controle uit oogpunt van preventie en snellere opsporing van strafbare feiten de extra dimensie is die in versneld tempo wordt gerealiseerd. Overigens zien we nationaal al de eerste aanzetten daartoe. De crimmele kaart van de commissie Gonzalves ${ }^{40}$ ten behoeve van de bestrijding van georganiseerde criminaliteit en de plannen om tot een verdergaande strafbaarstelling van voorbereidingshandelingen te komen, ${ }^{41}$ bieden meer dan aanknopingspunten voor deze transformatie van opsporing naar controle. ${ }^{42}$

De computergekoesterde verdenking is een logisch sequeel van deze benadering. Daarbij zal ook in het strafproces de computer geacht. worden gelijk te hebben, tenzij het tegendeel blijkt. Vragen over hoe de informatie de computer is ingegaan, wie dat gedaan heeft, en met welke bevoegdheid, welke informatie er verzameld is, hoe en op basis warvan, zouden wel eens minder passend kunnen zijn in een strafproces waarin de controle de basis voor de opsporing en vervolging is, en waarin de confrontatie ter zitting vervangen is door een overdosis aan technische en computergestuurde informatie.

De vraag dient zich aan wat in deze ontwikkeling de taak en positie van de advocaat is.

4h Rapport van de werkgroep bestrijding 2 ware georganiseerde criminaliteit, nowember 1987.

4 Rapport van de werkgroep strafbatetelling van voorbereidingshandelingan. Zie voorts mijn raktic daarop in dagblad Het parool, wa november ro8s: Strar voor beramen misdad droevig plan, en: M. Rutgers: Strafbaarstelling van voorbeteidingshandelingen ongewenst, in: DD $19(1989)$, p. 103-11y.

42 Zie hierover mijn dissertatic: Strafbare samenspanning, wen rechtshistorisch an rechtsvergelijkend onderzoek, diss. Utrecht, 1982 , Arnhown 1982 , alsmede mijn bijdrage an het crimineel Jarboek van de Coomhert Liga 1989. Breda 1989 Over de 'modernisering" wan het strafproces p. 4-10. Zie ook: Enhard Denninger. Der Präventions-Stat. in: Kritische Justiz, 1988, p. I-1.5.

Vgl. ook Klaus Rogall: Frontalangriff auf die Bïrgertechte oder notwendige Strafverfolgungsmasnahme? Zur Regelung der sog. Schleppnetzfathdung in 163d SuO in: NStZ, 1986, 9. P. 385 e.v. 


\section{De positie van de advocaat}

Een orientatie op de bestrijding van criminaliteit als primaire doelstelling van het strafproces biedt weing ruimte voor beginselen en individuele rechten die an een doelmatige funktonstichtige strafrechtspleging in de weg lijken te staan. Dat betekent niet dat de rechtsbeschermende beginselen daarmee hun betekenis hebben verloren, wel dat zij niet meer vanzelfsprekend zijn. Ze worden in het ordeningsperspectief geplatst tegenover de eisen van efficiency en snelheid, en van de belangenafweging die daarop volgt is voorspelbaar wat de uitkomst zal zijn in een tijd waarin criminaliteitsbestrijding wellhaast een magisch begrip is geworden. ${ }^{43}$ Deze individualisering van rechtsbeginselen bete-

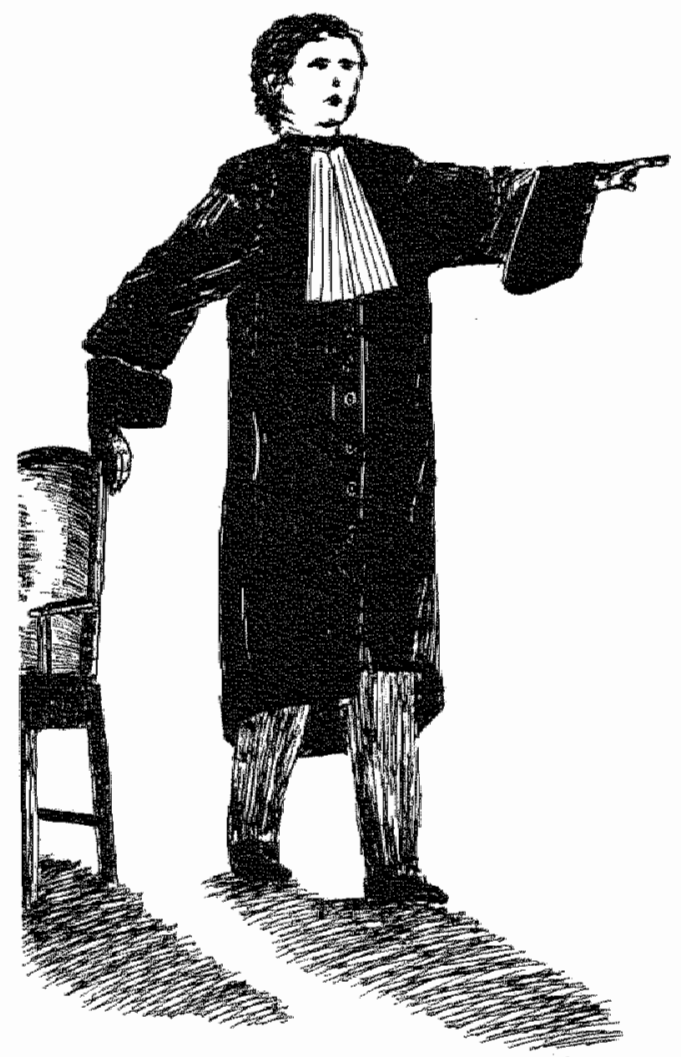

4s Vgl. Ecklate Riehle: Funktionstuchtige Strafechtsplege contra Strafprozessuale Garantien, in: Kritusche Justiz, 1980, p. 316-324. 
kent ook dat de verdachte er zich uitdrukkelijk op moet beroepen wil hij aanspraak maken op de beschermende werking ervan. In de praktik ligt daar een belangrijke taak voor de raadsman. Die tak wordt verzwand door de relativering van het confrontatiebeginsel en de daarmee samenhangende anonymisering van het strafproces 0 . m. door de computerisering als specifieke ontwikkelingstendens, en door de mede dankzij de technologische verworwenheden steeds groter wordende voorsprong van het Openbaar Ministerie, welke zich zal manifesteren in een $k$ wantitatieve en kwalitatieve toename van de technische rapporten, opgemaakt door terzake deskundigen welke voor thet OM daarvoor op afroep beschikbaar zijn. ${ }^{4+}$

De geschiedenis van het strafproces is de geschiedenis van de verdediging. Het is opvallend hoe weinig aandacht in de politiek en de wetenschap wordt besteed aan de rol en de positie van de radsman in een veranderend strafproces. Het verstoorde evenwicht vraagt uit oogpunt van een $\mathrm{kwalitatief}$ hoogstaande strafrechtspleging on een duidelijk antwoord van de kant van de verdediging, die daartoe in zijn algemeenheid onder meer door de afwezigheid van een specialistische opleiding en een nationaal en international georganiseerd verband niet is uitgerust. Haar bevoegdheden zouden moeten worden uitgebreid o.a. door toelating tot de verhoren van getuigen in de fase van het opsporingsonderzoek. Daamaast zou de verdediging meer inzicht moeten krijgen in en toegang tot geplande opsporingsakties en a anhoudingen. Het valt gegeven het gewijzigde beeld van het strafproces niet goed vol te houden waarom in voorkomende gevallen een select gezelschap journalisten wel, de raadsman niet wordt toegelaten tot bepalde opsporingsaktiviteiten. De tegenwerping dat de raadsman nog geen kliënt heeft kan worden ontweken door de op afroep beschikbare advocaat als geweten te laten opereren en als getuige die later ter zitting als zodanig kan verklaren wat is voorgevallen. Zouden er te weinig adwocaten beschikbaar zijn dan zou gedacht kunnen worden aan een systeem analoog aan dat van officier en hulpofficier van justitie, de hulpadvocaat die als zodanig optreedt en van zijn optreden verslag uitbrengt aan de

44 Vgl. Stephan Barton: Strafverteidigung und Kriminaltechnick, in: Strafwerteidiger, 3/1988. p. 124-1 30; Jürgen Crammenerl: Verceidigung im Strafram in: Strafverteidiger, $2 / 1988$. Zie ook nr. 1, 1989 van Justiticle Verkenningen, Criminalistick in Nederland, Arnhem rosg. 
radsman van de verdachte. Tot slot verdient aanbeveling te onderzoeken wat de mogelijkheden zijn van een eigen gerechtelijk laboratorium voor de verdediging, eventueel in Europees verband.

Op korte termijn kan de verdediging door een juiste waardering van het confrontatiebeginsel en door kennis van en inzicht in de wetenschap van de forensische psychologie gemotiveerd worden minder dan thans het geval is genoegen te nemen met de afbouw van een van de meest ten behoeve wan de verdediging ontwikkelde beginselen.

\section{Tot besluit}

\section{Ik kom tot een afronding}

In een rechtsstaat dient het uitgangspunt dat de executieve gecontroleerd wordt door de onafhankelijke rechter onwrikbaar verankerd te zijn. Aan dat uitgangspunt mag niet worden getornd. Ik heb betoogd dat dat uitgangspunt op de tocht stat en dan ook nog in het deel van het recht waarin van oudsher algemeen aanvaard is dat juist daarin die controle hard nodig is, niet in de laatste plats vanwege de vergaande bevoegdheden warover de overheid beschikt om in te grijpen in het leven wan de burger. De rechter lijkt bereid een deel van zijn taak door te schuiven naar het opsporingsapparat, terwijl dat apparaat zelf zo vindingrijk is om de rechter tot die afstand te verleiden. In deze zichzelf versterkende dans wordt het risico van onjuiste beslissingen aanvaard door de relativering wan de burgers beschermende rechtsbeginselen, zoals het onmiddellijkheidsbeginsel.

De rechter lijkt in toenemende mate voorzover hij het type van de onmiddellijke rechter representeert en als zodanig streeft naar de realisering van de optimumthese, in de Nederlandse strafrechtspleging een uitzonderingspositie in te nemen. De liberale rechterlijke taakopvatting warin het confrontatiebeginsel mede ten behoeve van de verwezenlij-

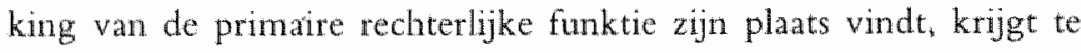
weinig ruimte binnen een kader warin ogenschijnlijk consensus bestat over de betekenis die moet worden toegekend aan de bestrijding van de criminaliteit als een van de funkties van het strafproces. Die ogenschijnlijke gelijkgestemdheid dankt zijn bestaan onder meer aan de van rijkswege te krap bemeten omvang van het rechterlijk apparaat warin 32 her rechtsstatelijk denken van de een onmiddellijk weerslag heeft op de 
agenda van de ander. Voor een structurele opleving van het confrontatiebeginsel is tenminste nodig het politieke besef dat goede rechtspraak kostbaar is.

Voor zover nodig kan de benodigde ruimte worden uitgelokt door uitspraken van de Europese Commissie en het Hof tot bescherming wan de rechten van de mens. ${ }^{45}$

Voor de verdediging geldt dat zij de mede ten gevolge van de relativering van het confrontatiebeginsel gebrekkige acceptatie van het beginsel van equality of arms gedwongen is tot andere strategieèn, met name ook gericht op een structurele verbetering van positie en faciliteiten.

45 Zie de eerder aangehaalde Kostovski-zaak, en de beslissing inzake Unterpertinger vs Oostenrijk $1 / 1985 / 87 / 134$. 
Degenen die hebben bijgedragen aan mijn benoeming dank ik voor het door hen in mij gestelde vertrouwen.

Hoogeache Peters, beste Toon,

We zijn ongeveer tegelijkertjid in Utrecht gearriveerd, jij als hoogleraar straf(proces)recht, ik als rechtenstudent. Je vertrok van het Willem Pompe Instituut kort nadat ik daar tewerk was gesteld. Van enig causal verband is mij nooit iets gebleken. De Utrechtse jaren waren bijzonder goede jaren, ook al zat jij later in je eigen instituut. Je creativiteit en daadkracht heb ik steeds als bijzonder inspirerend ervaren. Daarvoor en voor je nimmer aflatende persoonlijke interesse en voor de vriendschap die ons bindt, ben ik je zeer erkentelijk.

Leden wan de vakgroep strafrechi en criminologie,

Als relatief kleine vakgroep die bovendien werkzaam is binnen een rechtsgebied dat voortdurend spanningen oproept, is het zaak een arbeidsklimaat te scheppen dat zich kenmerkt door een grote mate van openheid en betrokkenheid. De problemen waarmee ons vak en wij niet minder worstelen, zijn weliswaar niet allemaal even nieuw, maar vragen wel steeds om nieuwe creatieve antwoorden, waarmee een bijdrage wordt geleverd aan het verhogen van het rechtvaardigheidsgehalte van de samenleving in het algeneen, en van de strafrechtspleging in het bijzonder.

Dames en heren leden wan de juridische faculteit,

Zoals zovelen van $U$ ervar ik het werken in de juridische faculteit van deze instellingals enerverend en boeiend, maar ook als zeer vermoeiend. Dat latste heeft alles te maken met de organisatie van de faculteit en de onderwijsbelasting, die met name hoog lijkt door de versnippering van 34 tijd en energie. Of hier sprake is van een kinderziekte zal binnen korte 
tijd duidelijk moeten worden. Wellicht dat we bij onze medische broeders te rade moeten gaan.

\section{Dames en heren studenten,}

Het strafrecht is een problematisch vakgebied dat zich bij uitstek leent voor het probleemgestuurd onderwijs dat erop gericht moet zijn $U$ vertrouwd te maken met achterliggende vragen en problemen van wisselende omvang. Het is tegelijkertijd een uiterst boeiend deelgebied van het recht vanwege de dynamiek die er met name door creatieve juristen en politici wordt ingebracht. Ik stel mij voor bij U meer dan normale belangstelling voor het strafrecht met toebehoren op te wekken, en met name voor die aspecten die van essentiële betekenis zijn voor een meer rechtvaardige strafrechtspleging.

\section{Lieve ouders,}

Mijn wijze van denken over het recht en de inrichting van de samenleving vindt zijn oorsprong in de voorbeeldfunktie die $U$ in uw lange leven hebt vervuld. Ik ben $\mathrm{U}$ daarvoor zeer erkentelijk.

Lieve Maria, Claire, Violette, Daniël, Iris, Sylvian,

Ik ben me ervan bewust dat het niet altijd meevalt samen te wonen met iemand die teveel tijd in zijn werk stopt. Dat zou in een andere baan vrees ik niet anders zijn. Die energie zou overigens zonder jullie liefde en betrokkenheid niet zijn op te brengen.

Ik dank U voor Uw aandacht. 